\title{
ANALISIS TINGKAT KEPARAHAN PENYAKIT KARAT DAUN PADA TANAMAN KOPI ARABIKA DI KEBUN PERCOBAAN FAKULTAS PERTANIAN UNIVERSITAS WINAYA MUKTI TANJUNGSARI
}

\author{
Lia Sugiarti \\ Fakultas Pertanian Universitas Winaya Mukti \\ E-mail : liasugiarti82@gmail.com
}

\begin{abstract}
ABSTRAK
Tujuan penelitian ini adalah untuk mengetahui tingkat keparahan penyakit karat daun (Hemileia vastatrix). Penelitian dilaksanakan di Kebun Kopi Kebun Percobaan dan koleksi Fakultas Pertanian Universitas Winaya Mukti, dengan ketinggian tempat $800 \mathrm{~m}$ di atas permukaan laut dan tanahnya termasuk ordo Andisol. Penelitian dilaksanakan pada tanggal 16 April 2015. Bahan yang digunakan meliputi pohon kopi Arabika. Metode acak dengan perhitungan analisis intensitas penyakit tanaman. Hasil penelitian menunjukan bahwa : intesitas serangan penyakit karat daun (Hemileia vastatrix) yang paling tinggi adalah $90 \%$ termasuk ke dalam skala kerusakan tingkat 5.
\end{abstract}

Kata kunci : Tanaman Kopi Arabika, Penyakit Karat Daun, Hemileia vastatrix

\begin{abstract}
The pupose of this research are to know the level of severity In Coffe Leaf Rust (Hemileia vastatrix) diseases. This research was conducted in the Coffe's Garden of the Faculty of Agriculture of Winaya Mukti University at April 16 2015. The treatments of coffe trees arabica. Random of Methode with calculation the analys of intensity plant diseases. The result showed that :intensity coffe leaf rust (Hemileia vastatrix) diseases on high level is $90 \%$ was the clasification of level damage 5.
\end{abstract}




\section{PENDAHULUAN}

Kopi merupakan komoditas perkebunan yang memegang peranan penting dalam perekonomian Indonesia. Komoditas ini diperkirakan menjadi sumber pendapatan utama tidak kurang dari 1,84 juta keluarga yang sebagian besar mendiami kawasan pedesaan di wilayah-wilayah terpencil. Kopi merupakan komoditas ekspor penting bagi Indonesia yang mampu menyumbang devisa yang cukup besar (Ditjenbun, 2014).

Sebagai negara produsen kopi terbesar ketiga di dunia, Indonesia sudah mulai tergeser oleh Vietnam, hal ini disebabkan kopi Indonesia kurang memiliki daya saing akibat rendahnya produktivitas, yaitu hanya $539 \mathrm{~kg}$ biji kering/ha/tahun dibandingkan dengan negara produsen utama lainnya seperti Vietnam (1.540 $\mathrm{kg} / \mathrm{ha} /$ tahun), Kolumbia (1.220 kg/ha/tahun) dan Brasil (1.000 kg/ha/tahun) (Ditjenbun, 2009 dalam Mahfud, M.C, 2012).

Rendahnya produktivitas kopi Indonesia antara lain disebabkan oleh tingginya gangguan penyakit karat daun sebagai akibat belum diterapkannya praktik kultur teknis yang benar, termasuk pengendalian penyakit karat daun, terutama pada perkebunan rakyat yang luasnya 1.241 .500 ha $(95,5 \%$ dari luas tanaman kopi) (Mahfud et al, 2000).

Penyakit karat daun yang disebabkan oleh Hemileia vastatrix merupakan penyakit yang sangat merugikan pada tanaman kopi (Semangun, 2000 dalam Harni, 2015). Penyakit ini sudah berkembang di Indonesia sejak tahun 1876 dan dalam perkembangannya mengakibatkan penurunan produksi kopi hingga $25 \%$ (Semangun, 2000 dalam Harni 2015).

Perkembangan penyakit tanaman ini dipengaruhi oleh tiga faktor, yaitu patogen, inang dan tanaman (Mahfud dkk, 1991). Di daerah tropis, Hemileia vastatrix bertahan sebagai uredospora (spora jamur karat), uredium (badan buah penghasil uredospora), dan miselium (kumpulan hifa jamur karat) pada daun sakit untuk melanjutkan infeksi pada tanaman. Dari beberapa struktur jamur tersebut, uredospora paling berperan dalam perkembangan penyakit karat daun. Uredospora jamur Hemileia vastatrix berwarna orange, panjang 25-35 $\mu \mathrm{m}$ dan lebar 12-28 $\mu \mathrm{m}$, berbentuk seperti ginjal dan berduri pada bagian yang cembung (Kushalappa, 1989). Tingkat kerusakan tanaman kopi pada perkebunan rakyat di Indonesia yang mencapai $58 \%$ mengindikasikan lingkungan pertanaman kopi mendukung perkembangan penyakit karat daun (Rosmahani et al, 2003).

Gejala serangan penyakit karat daun dapat dilihat pada permukaan atas dan bawah daun, ditandai dengan bercak kuning jingga seperti serbuk (powder) (Agrios, 2005). Jika diamati pada bagian bawah daun tampak bercak yang awalnya berwarna kuning muda, selanjutnya akan berubah menjadi kuning tua, pada bagian tersebut akan terlihat jelas tepung yang berwarna orange atau jingga. Tepung yang berwarna orange atau jingga tersebut adalah uredospora jamur Hemileia vastatrix. Gejala lanjut, pada daun tampak bercak cokelat saling bergabung, menjadi lebih besar, 
kemudian mengering dan gugur sehingga tanaman menjadi gundul (Semangun 2000 dalam Harni 2015).

Penelitian bertujuan untuk mengetahui tingkat intensitas keparahan penyakit karat daun (Hemileia vastatrix) yang ada di kebun percobaan dan koleksi Fakultas Pertanian Universitas Winaya Mukti.

\section{BAHAN DAN METODE}

Penelitian dilaksanakan di Kebun Kopi Kebun Percobaan dan koleksi Fakultas Pertanian Universitas Winaya Mukti, dengan ketinggian tempat $800 \mathrm{~m}$ di atas permukaan laut dan tanahnya termasuk ordo Andisol. Penelitian dilaksanakan pada tanggal 16 April 2015.

Bahan yang digunakan meliputi pohon kopi Arabika. Alat-alat yang digunakan adalah alat tulis, kaca pembesar, kalkulator.

Pengamatan dilakukan terhadap daun-daun tanaman kopi dari beberapa pohon pada luasan tertentu yang terserang penyakit karat daun (Hemileia vastatrix). Pengamatan dilakukan terhadap semua contoh perlakuan dengan cara memilih 4 pohon kopi secara acak, kemudian dianalisis sesuai dengan skor (nilai) keparahan serangan penyakit tanaman.

Tabel 1. Sistem Skoring Keparahan Penyakit

\begin{tabular}{cc}
\hline Skor (nilai) & Kriteria \\
\hline 1 & Tidak ada gejala \\
2 & Gejala ringan $20 \%$ \\
3 & Gejala sedang $40 \%$ \\
4 & Gejala meluas $80 \%$ \\
5 & Tanaman Mati \\
\hline
\end{tabular}

Tabel 2. Skala Tingkat Kerusakan Tanaman

\begin{tabular}{cc}
\hline Nilai Skala & Tingkat Kerusakan Tanaman $(\%)$ \\
\hline 0 & Tidak ada serangan gejala \\
1 & $>0-20$ \\
2 & $>20-40$ \\
3 & $>40-60$ \\
4 & $>60-80$ \\
5 & $>80--100$ \\
\hline
\end{tabular}

Sumber : Lologau, 2006. 


\section{HASIL DAN PEMBAHASAN}

\section{Hasil Pengamatan}

1) Intensitas serangan penyakit karat daun kopi (Hemileia vastatrix)

Data hasil pengamatan serangan penyakit karat daun kopi (Hemileia vastatrix) pada pohon ke-1 dapat dilihat pada tabel 3, sebagai berikut :

\section{Tabel 3. Data Pengamatan Serangan Penyakit Karat Daun Kopi} (Hemileia vastatrix) Pada Pohon Ke-1

\begin{tabular}{|c|c|c|c|}
\hline Cabang ke- & Kriteria daun & Skor (\%) & Jumlah \\
\hline \multirow[t]{5}{*}{ I } & Sehat & 1 & 5 \\
\hline & $20 \%$ & 2 & 4 \\
\hline & $40 \%$ & 3 & 3 \\
\hline & $80 \%$ & 4 & 1 \\
\hline & Mati & 5 & 0 \\
\hline \multirow[t]{5}{*}{ II } & Sehat & 1 & 2 \\
\hline & $20 \%$ & 2 & 2 \\
\hline & $40 \%$ & 3 & 3 \\
\hline & $80 \%$ & 4 & 5 \\
\hline & Mati & 5 & 0 \\
\hline \multirow[t]{5}{*}{ III } & Sehat & 1 & 3 \\
\hline & $20 \%$ & 2 & 1 \\
\hline & $40 \%$ & 3 & 5 \\
\hline & $80 \%$ & 4 & 1 \\
\hline & Mati & 5 & 0 \\
\hline \multirow[t]{5}{*}{ IV } & Sehat & 1 & 0 \\
\hline & $20 \%$ & 2 & 2 \\
\hline & $40 \%$ & 3 & 2 \\
\hline & $80 \%$ & 4 & 2 \\
\hline & Mati & 5 & 0 \\
\hline \multirow[t]{5}{*}{ V } & Sehat & 1 & 4 \\
\hline & $20 \%$ & 2 & 4 \\
\hline & $40 \%$ & 3 & 2 \\
\hline & $80 \%$ & 4 & 1 \\
\hline & Mati & 5 & 0 \\
\hline
\end{tabular}

Berdasarkan data diatas maka intensitas serangan penyakit karat daun (Hemileia vastatrix) sebagai berikut : Nilai intensitas serangan penyakit pohon ke 1 yaitu sebesar 39,9\% sehingga termasuk tingkat kerusakan tanaman pada skala 2.

\section{2) Intensitas serangan penyakit karat daun kopi (Hemileia vastatrix)}

Data hasil pengamatan serangan penyakit karat daun kopi (Hemileia vastatrix) pada pohon ke-2 dapat dilihat pada tabel 4, sebagai berikut : Berdasarkan 
data tersebut maka intensitas serangan penyakit karat daun (Hemileia vastatrix) sebagai berikut :

Tabel 4. Data Pengamatan Serangan Penyakit Karat Daun Kopi (Hemileia vastatrix) Pada Pohon Ke-2

\begin{tabular}{|c|c|c|c|c|}
\hline CABANG & $\begin{array}{c}\text { KRITERIA } \\
\text { DAUN }\end{array}$ & $\operatorname{SKOR}(\%)$ & NILAI & JUMLAH DAUN \\
\hline \multirow[t]{5}{*}{$\mathrm{I}$} & Sehat & 0 & 1 & 0 \\
\hline & $20 \%$ & 20 & 2 & 2 \\
\hline & $40 \%$ & 40 & 3 & 1 \\
\hline & $80 \%$ & 80 & 4 & 2 \\
\hline & Mati & 0 & 5 & 0 \\
\hline \multirow[t]{5}{*}{ II } & Sehat & 0 & 1 & 1 \\
\hline & $20 \%$ & 20 & 2 & 2 \\
\hline & $40 \%$ & 40 & 3 & 1 \\
\hline & $80 \%$ & 80 & 4 & 1 \\
\hline & Mati & 0 & 5 & 0 \\
\hline \multirow[t]{5}{*}{ III } & Sehat & 0 & 1 & 4 \\
\hline & $20 \%$ & 20 & 2 & 0 \\
\hline & $40 \%$ & 40 & 3 & 0 \\
\hline & $80 \%$ & 80 & 4 & 3 \\
\hline & Mati & 0 & 5 & 0 \\
\hline \multirow[t]{5}{*}{ IV } & Sehat & 0 & 1 & 4 \\
\hline & $20 \%$ & 20 & 2 & 0 \\
\hline & $40 \%$ & 40 & 3 & 2 \\
\hline & $80 \%$ & 80 & 4 & 4 \\
\hline & Mati & 0 & 5 & 0 \\
\hline \multirow[t]{5}{*}{ V } & Sehat & 0 & 1 & 0 \\
\hline & $20 \%$ & 20 & 2 & 0 \\
\hline & $40 \%$ & 40 & 3 & 2 \\
\hline & $80 \%$ & 80 & 4 & 2 \\
\hline & Mati & 0 & 5 & 0 \\
\hline
\end{tabular}

Nilai intensitas serangan penyakit pohon ke 2 yaitu sebesar $51 \%$ sehingga termasuk tingkat kerusakan tanaman pada skala 3.

\section{3) Intensitas serangan penyakit karat daun kopi (Hemileia vastatrix)}

Data hasil pengamatan serangan penyakit karat daun kopi (Hemileia vastatrix) pada pohon ke-3 dapat dilihat pada tabel 5, sebagai berikut :

Berdasarkan data tersebut maka intensitas serangan penyakit karat daun (Hemileia vastatrix) sebagai berikut : 
Tabel 5. Data Pengamatan Serangan Penyakit Karat Daun Kopi (Hemileia vastatrix) Pada Pohon Ke-3

\begin{tabular}{|c|c|c|c|c|}
\hline CABANG & $\begin{array}{c}\text { KRITERIA } \\
\text { DAUN }\end{array}$ & SKOR (\%) & NILAI & $\begin{array}{c}\text { JUMLAH } \\
\text { DAUN }\end{array}$ \\
\hline \multirow[t]{5}{*}{ I } & Sehat & 0 & 1 & 4 \\
\hline & $20 \%$ & 20 & 2 & 3 \\
\hline & $40 \%$ & 40 & 3 & 0 \\
\hline & $80 \%$ & 80 & 4 & 7 \\
\hline & Mati & 0 & 5 & 0 \\
\hline \multirow[t]{5}{*}{ II } & Sehat & 0 & 1 & 2 \\
\hline & $20 \%$ & 20 & 2 & 5 \\
\hline & $40 \%$ & 40 & 3 & 3 \\
\hline & $80 \%$ & 80 & 4 & 0 \\
\hline & Mati & 0 & 5 & 0 \\
\hline \multirow[t]{5}{*}{ III } & Sehat & 0 & 1 & 0 \\
\hline & $20 \%$ & 20 & 2 & 3 \\
\hline & $40 \%$ & 40 & 3 & 2 \\
\hline & $80 \%$ & 80 & 4 & 3 \\
\hline & Mati & 0 & 5 & 0 \\
\hline \multirow[t]{5}{*}{ IV } & Sehat & 0 & 1 & 0 \\
\hline & $20 \%$ & 20 & 2 & 0 \\
\hline & $40 \%$ & 40 & 3 & 2 \\
\hline & $80 \%$ & 80 & 4 & 1 \\
\hline & Mati & 0 & 5 & 0 \\
\hline \multirow[t]{5}{*}{ V } & Sehat & 0 & 1 & 0 \\
\hline & $20 \%$ & 20 & 2 & 2 \\
\hline & $40 \%$ & 40 & 3 & 3 \\
\hline & $80 \%$ & 80 & 4 & 4 \\
\hline & Mati & 0 & 5 & 0 \\
\hline
\end{tabular}

Nilai intensitas serangan penyakit pohon ke 3 yaitu sebesar $52 \%$ sehingga termasuk tingkat kerusakan tanaman pada skala 3.

\section{4) Intensitas serangan penyakit karat daun kopi (Hemileia vastatrix)}

Data hasil pengamatan serangan penyakit karat daun kopi (Hemileia vastatrix) pada pohon ke-2 dapat dilihat pada tabel 5, sebagai berikut : 
Tabel 6. Data Pengamatan Serangan Penyakit Karat Daun Kopi (Hemileia vastatrix) Pada Pohon Ke-4

\begin{tabular}{|c|c|c|c|c|}
\hline CABANG & $\begin{array}{c}\text { KRITERIA } \\
\text { DAUN }\end{array}$ & $\operatorname{SKOR}(\%)$ & NILAI & JUMLAH DAUN \\
\hline \multirow[t]{5}{*}{ I } & Sehat & 0 & 1 & 3 \\
\hline & $20 \%$ & 20 & 2 & 2 \\
\hline & $40 \%$ & 40 & 3 & 2 \\
\hline & $80 \%$ & 80 & 4 & 2 \\
\hline & Mati & 0 & 5 & 0 \\
\hline \multirow[t]{5}{*}{ II } & Sehat & 0 & 1 & 4 \\
\hline & $20 \%$ & 20 & 2 & 2 \\
\hline & $40 \%$ & 40 & 3 & 4 \\
\hline & $80 \%$ & 80 & 4 & 1 \\
\hline & Mati & 0 & 5 & 0 \\
\hline \multirow[t]{5}{*}{ III } & Sehat & 0 & 1 & 2 \\
\hline & $20 \%$ & 20 & 2 & 0 \\
\hline & $40 \%$ & 40 & 3 & 4 \\
\hline & $80 \%$ & 80 & 4 & 4 \\
\hline & Mati & 0 & 5 & 0 \\
\hline \multirow[t]{5}{*}{ IV } & Sehat & 0 & 1 & 0 \\
\hline & $20 \%$ & 20 & 2 & 1 \\
\hline & $40 \%$ & 40 & 3 & 1 \\
\hline & $80 \%$ & 80 & 4 & 2 \\
\hline & Mati & 0 & 5 & 0 \\
\hline \multirow[t]{5}{*}{$\mathrm{V}$} & Sehat & 0 & 1 & 1 \\
\hline & $20 \%$ & 20 & 2 & 2 \\
\hline & $40 \%$ & 40 & 3 & 0 \\
\hline & $80 \%$ & 80 & 4 & 1 \\
\hline & Mati & 0 & 5 & 0 \\
\hline
\end{tabular}

Berdasarkan data diatas maka intensitas serangan penyakit karat daun (Hemileia vastatrix) sebagai berikut : Nilai intensitas serangan penyakit pohon ke 4 yaitu sebesar $90 \%$ sehingga termasuk tingkat kerusakan tanaman pada skala 5 .

\section{PEMBAHASAN}

Hasil penelitian menunjukkan bahwa intensitas serangan penyakit karat daun pada tanaman kopi sangat bervariasi, antara $30 \%$ - $90 \%$. Untuk serangan tertinggi yaitu pada pohon ke 4 sebesar $90 \%$. Dari pengamatan tersebut maka ratarata intensitas serangan penyakit karat daun pada tanaman kopi masih relatif sedang, belum sampai ke tahap keparahan. Hal ini disebabkan karena curah hujannya tergolong rendah atau sudah masuk musim kemarau. 
Faktor lingkungan yang mempengaruhi perkembangan penyakit antara lain adalah suhu, kelembaban udara, curah hujan, dan sinar matahari (McCartney 1994, Brown et al 1995). Suhu diatas $150 \mathrm{C}$ di sekitar tanaman kopi menghambat perkembangan penyakit (Brown et al 1995). Hujan berperan dalam meningkatkan kelembapan sehingga cocok bagi perkecambahan uredospora dan penyebaran jamur Hemileia vastatrix. Sinar matahari langsung ke permukaan daun menghambat proses perkecambahan uredospora dan memperpanjang periode inkubasi penyakit karat daun (McCartney, 1994).

Keadaan kebun percobaan yang memang terlalu rimbun juga sangat mempengaruhi kehidupan jamur Hemileia vastatrix. Jenis kopi, umur tanaman, dan kerapatan daun mempengaruhi perkembangan penyakit karat daun. Tanaman kopi jenis arabika lebih peka terhadap penyakit karat daun dibandingkan jenis robusta. (Hulupi, 1998, Sri Sukamto, 1998). Jika posisi daun tidak rapat, uredospora jamur Hemileia vastatrix yang sampai ke tanaman kopi akan banyak yang jatuh ke tanah. Sebaliknya jika posisi daun rapat, permukaan tanaman menjadi luas yang memungkinkan semua uredospora yang sampai ke tanaman kopi menempel pada daun sehingga tersedia banyak sumber penyakit (Patridge, 1997 dalam Mahfud, 2012). Daun yang saling bersentuhan akan memudahkan perkembangan penyakit, disamping meningkatkan kelemabapan lingkungan yang memacu infeksi dan perkembangan cendawan Hemileia vastatrix (Priyo, 2014).

Hemileia vastatrix mempunyai siklus hidup yang sederhana. Jika uredospora sampai pada daun yang peka, misalnya daun muda, uredospora berkecambah dan secara cepat menginfeksi daun melalui stomata pada permukaan daun bagian bawah. Dalam tempo 10 - 20 hari, pada permukaan daun bagian bawah terbentuk uredospora baru oleh uredium yang keluar lewat stomata. Tiap uredium menghasilkan +70.000 uredospora dalam 3- 5 bulan sebagai sumber penularan penyakit yang sangat potensial. Karena kopi merupakan tahnaman tahunan, pembentukan daun berlangsung sepanjang tahun sehingga memungkinkan jamur tersebut hidup dan terus berkembang setiap saat (Agnihotrudu, 1992).

Tingginya intensitas serangan penyakit karat daun disebabkan juga oleh karena penyakit atau patogen sudah bertahan lama di areal pertanaman kopi tersebut.

\section{KESIMPULAN}

Dari pelaksanaan percobaan diatas dapat diambil kesimpulan sebagai berikut bahwa:

1. Intesitas serangan penyakit karat daun (Hemileia vastatrix) yang paling tinggi adalah $90 \%$ termasuk ke dalam skala kerusakan tingkat 5 .

2. Tingginya intensitas serangan penyakit tersebut disebabkan karena penyakit sudah bertahan lama di areal pertanaman kopi tersebut. 


\section{SARAN}

Perlu dilakukan pengamatan lebih lanjut agar diperoleh cara pengendalian yang tepat untuk mengurangi intensitas tingkat keparahan penyakit karat daun pada tanaman kopi tersebut. Sehingga produktivitas dari kopi tersebut bisa meningkat.

\section{DAFTAR PUSTAKA}

Agnitrudu. 1992. Leaf Rust of Coffe. P.190-201. In Plant Disease of International Importance. Prentice-Hall, Inc., New Jersey, USA.

Agrios, G. N. 2005. Plan Pathology. P.922. Fifth Edition, USA : Elsevier Academic Press.

Brown et al. 1995. The Effect of Coffe Leaf Rust on Foliation and Yield of Coffe in Papua New Guinea. Crop Prot. 14 (7). 589-592.

Ditjenbun (Direktorat Jenderal Perkebunan). 2006. Arah Kebijakan Pengembangan Kopi di Indonesia. Makalah Simposium Kopi 2006, Surabaya, 2-3 Agustus 2006. Pusat Penelitian Kopi dan Kakao Indonesia, Jember. 8 Hlm.

Ditjenbun (Direktorat Jenderal Perkebunan). 2009. Statistik Perkebunan Kopi 2008-2010. Ditjenbun, Jakarta. 79 hlm.

Ditjenbun (Direktorat Jenderal Perkebunan). 2014. Budidaya Tanaman Kopi. ditjenbun.pertanian.go.id diakses tanggal 11-08-2017.

Harni, R. Dkk. 2015. Ketahanan Induk Kopi Liberika Terhadap Penyakit Karat Daun (Hemileia vastatrix) di Kepulauan Meranti. J.TIDP 2 (1) 35-42, Maret 2015. Diakses tanggal 14-00-2018.

Hulupi, R. 1998. Penggunaan Bahan TanamanTahan Dalam Mengendalikan Hama-Penyakit. Kumpulan Materi Pelatihan Pengelolaan Organisme Penganggu Tanaman Kopi. Pusat Penelitian Kopi dan Kakao. Jember, 12 hlm.

Kushalappa. 1989. Rust Management; An Epidomologi Approach and Chemical Control, p 84-94. In Coffe Rust : Epidomoligy, Resistance and Management. CRC Press, Inc. Florida.

Lologau, Baso Aliem. 2006. Tingkat serangan lalat pengorok daun, liriomyza huidobrensis (blanchard) dan kehilangan hasil pada tanaman kentang. Balai Pengkajian Teknologi Pertanian Sulawesi Selatan.

Mahfud, M.C. 1991. Ketahanan Beberapa Jenis Jeruk Terhadap Penyakit Embun Tepung. Jurnal Hortikultura 1 (2) 54-57.

Mahfud, M.C., L.Rosmahani., D. Rachmawati., Handoko., dan Sarwono. 2000. Kajian Pengelolaan Hama Terpadu (PHT) Pada Tanaman Kopi. Prosiding Seminar Hasil Penelitian/ Pengkajian Teknologi Pertanian Mendukung Ketahanan Pangan Berwawasan Agribisnis, Malang 8- 9 Agustus 2000. Pusat Penelitian dan Pengembangan Sosial Ekonomi Pertanian, Bogor. 507-518. 
Mahfud M, C. 2012. Teknologi dan Strategi Pengendalian Penyakit Karat Daun Untuk Meningkatkan Produksi Kopi Nasional. Pengembangan Inovasi Pertanian 5 (1), 2012. Hlm 44-57.

MC, Cartney, HA. 1994. Spore Disperal : Enviromnental and Biological Factors In Ecology of Plan Pathogen. Walingford. CAB International. Pp 172181.

Patridge,J.E.1997.CoffeRust,http://plantpath.unl.edu/peartree/homer/diseas.skp/ho rt/trees/cofferst.html (6April 2004)

Priyo, Kridanto D. 2014. Penyakit Karat Daun Tanaman Kopi. www.agronomer.com/2014/08/penyakit-karat-daun-hemileia.html Diakses 11 Agustus 2017

Rosmahani, L. MC, Mahfud, Handoko, D. Rahmawati, Sarwono, M. Soleh dan H. Subagio. 2003. Uji Penerapan Teknologi PHT Tingkat Petani Oleh Petani Pada Kopi Arabika Rakyat di Dataran Tinggi. Prosiding Seminar dan Ekspose Teknologi BPTP Jatim, Malang, 9-10 Juli 2002. Pusat Penelitian dan Pengembangan Sosial Ekonomi Pertanian, Bogor. Hlm 441-453.

Semangun, H. 2000. Penyakit-penyakit Tanaman Perkebunan Indonesia. Yogyakarta, Gajah Mada University. $835 \mathrm{hlm}$.

Sukamto, Sri. 1998. Pengelolaan Penyakit Tanaman Kopi. Kumpulan Materi Pelatihan Pengelolaan Organisme Penganggu Tanaman Kopi. Pusat Penelitian Kopi dan Kakao. Jember, 15 hlm. 